Article

\title{
Housing Wealth Status and Informal Accumulation of Rural Villages at the Rural-Urban Fringe in Shanghai, China
}

\author{
Jin Xie ${ }^{1,2}$, Yinying Cai ${ }^{1, *}$, Hang Tang ${ }^{3}$ and Yuanqin Liao ${ }^{3}$ \\ 1 College of Public Administration, Huazhong Agricultural University, Wuhan 430070, China; \\ xiejin@berkeley.edu \\ 2 Department of Environmental Science, Policy, and Management, University of California, \\ Berkeley, CA 94720, USA \\ 3 Shanghai Institute of Land Resource Survey, Shanghai 200072, China; feitianwuzhe@aliyun.com (H.T.); \\ liaoyuanqin@163.com (Y.L.) \\ * Correspondence: caiyinying@mail.hzau.edu.cn
}

Received: 3 July 2020; Accepted: 21 August 2020; Published: 24 August 2020

\begin{abstract}
Housing wealth among urban residents has been a hotspot issue, but there is a dearth of literature focusing on rural housing wealth. Using housing registration data in Shanghai, this study examines the status and accumulation of rural housing wealth at the rural-urban fringe. Results show that rural housing wealth at the rural-urban fringe is characterized by high stock and frequent extension and reconstruction dominated by auxiliary houses. Rural housing wealth is still relatively equitable, but compared to their initial housing wealth distribution, disparities in urban villages or suburban villages are obviously higher than in the outer suburbs. These disparities are mainly driven by the expansion and reconstruction of rural auxiliary houses, typically the horizontal expansion of auxiliary homes. We suggest that defining explicit construction rules for rural auxiliary will help to avoid the disorder increase in illegal housing and, subsequently, rural housing wealth disparity.
\end{abstract}

Keywords: housing wealth; rural villages; disparity status; informal accumulation; rural-urban fringe; Shanghai

\section{Introduction}

Since the reform and opening up of land development more than 40 years ago, urban land use has transferred from incremental expansion to inventory optimization, tapping into potential and intensive use, promoting high-quality and sustainable development. The large scale of rural residential land in urban villages and suburban villages at the rural-urban fringe offers a major way for local governments to revitalize stock construction land and overcome bottlenecks in urban development space [1,2]. Nowadays, the total amount of construction land in rural China, whose land layout is scattered, disorganized and intermixed with extensive uses, is 4.6 times the total amount of construction land available in cities (http://www.gov.cn/jrzg/2006-02/18/content_203328.htm). Some rural residential areas are as much as $300 \mathrm{~m}^{2}$ per capita, far exceeding the national standard ceiling (http://www.gov.cn/ zhengce/content/2017-02/04/content_5165309.htm).

Rural housing refers to the housing invested in and constructed by rural families relying on homesteads collectively distributed to community members, a basic residential security and welfare system granted to farmers in China [3]. Since the founding of the People's Republic of China, the system has realized the dream for rural households of "shelter for all" and "home ownership for all" in rural China, and has greatly improved the housing conditions and living environment of rural families in China. According to research reports of the China Household 
Finance Survey (CHFS), China's rural housing ownership rate reached 97.2\% in 2017 (https://chfs. swufe.edu.cn/thinktank/resultsreport.html?id=1664?id=1664). Chinese National Statistics Data shows that the per capita housing area for rural residents increased from $8.1 \mathrm{~m}^{2}$ in 1978 to $47.3 \mathrm{~m}^{2}$ in 2018 (http://www.stats.gov.cn/tjsj/zxfb/201907/t20190731_1683002.html). In order to ensure fairness and effectiveness, strict restrictions were placed on the entry of rural homesteads into the market. It was defined legally that every rural household had the right to apply for one free plot to build a home and use the land, but they do not have transfer rights. Despite the fact that farmers cannot benefit from scales or property appreciation through market transactions of their collectively-owned construction land, they can freely occupy and use it in a system of usufructuary rights. This has resulted in an initial and sharp expansion of rural homestead area [4].

Furthermore, with industrialization and urbanization, rural land and real estate value at the rural-urban fringe are continuously increasing, and in the absence of the opportunity to sell properties, informal rental markets for rural housing are becoming prevalent $[1,5,6]$. The rural-urban fringe is the transition region between urban and rural areas, with superior location conditions and public service facilities compared to more distant rural areas. The household industrial and commercial operations are most active at the rural-urban fringe. The multifunctional advantages of housing assets at the rural-urban fringe make their wealth effect obvious $[7,8]$. Driven by this opportunity to acquire wealth, rural housing at the rural-urban fringe is prone to illegal construction, expansion, and reconstruction, particularly in urban villages [9]. Research shows that the pattern of homogeneity, closedness, exclusivity, and self-sufficiency, formerly characteristic of rural housing at the rural-urban fringe, is being broken, and the spatial isolation implied by "Housing Status Groups" is rapidly emerging $[10,11]$. However, extant studies on China's housing conditions and wealth differentiation have mainly focused on urban China and rural-urban regions [12,13], and fewer studies quantitatively examine rural housing wealth differentiation and accumulation processes. The two main reasons lie in the non-market distribution of rural homesteads as well as the difficulty in collecting micro data about rural housing wealth [14]. Moreover, most research has found that households' capacity seemed best able to explain the processes of accumulation of housing wealth [15]. With rising urban commercial housing prices and the development of informal housing markets, housing area is regarded as an important indicator of the housing assets of rural households at the rural-urban fringe. Without planning and development control, rural households build the largest houses they can. Thus, housing differentiation has emerged among rural households who possess different quantities and types of capital, rights and entitlements, skills, and other assets [16]. Related researches found case studies were based on random sampling, and there was a dearth of literature for analyzing the status and drives of rural housing wealth disparity in China, especially using a full-sample analysis.

This study aims to provide an assessment of housing wealth disparity at the rural-urban fringe, and offers a detailed explanation for the formation of preliminary differentiation in accumulation. The research data was sourced from the Shanghai Institute of Land Resources Survey, including the rural comprehensive housing registration dataset and covering all households. It provides detailed data for analyzing the wealth differentiation and accumulation processes underlying rural housing wealth disparity, including population, construction area, homestead area, building floors, initial housing area, and housing expansion processes.

We use Kangqiao Town of the Pudong New Area in Shanghai as a study area, analyzing rural housing disparity and accumulation processes. Rural residential land occupies a total area of $800 \mathrm{~km}^{2}$ in Shanghai. Its "scattered, disorderly, low-quality, weak, and old" layout has restrained the high-quality development of cities [17]. In view of that, Shanghai took the lead in proposing the policy of surface reduction for construction land, taking rural homesteads as the main target. In 2017, the approved "Shanghai Master Plan (2017-2035)" explicitly characterized the city's developmental pattern as "bottom-line control, endogenous development, and flexible adaptation", and it intended to implement the strategy of controlling and reducing urban construction land. Recently, Shanghai has taken many innovative measures to revitalize rural residential land at the rural-urban fringe. For one, the policy 
of exchanging rural homesteads was introduced to encourage the concentration of rural housings in suburban villages at the rural-urban fringe, thereby promoting the intensive use of rural residential land, and solving a series of problems including the insufficiency of urban construction land quotas and the need for spatial optimization. In addition, efforts were made to further intensify "three-old" transformation (i.e., transformation of old towns, old factories, and old villages), and especially expand the transformation of urban villages at the rural-urban fringe. These urban renewal measures improved the floor area ratio of residential land, thus increasing the supply of urban residential area. In specific, Kangqiao Town, located in the hinterland of Pudong New Area, is a pilot town of rural homestead system reform and construction land reduction in Shanghai. The town has 16 administrative villages and 34 communities, with a land area of $41.25 \mathrm{~km}^{2}$; its population is 283,200 . It is also characterized by a rural-urban fringe, with convenient transportation, an advanced economy, and a large number of migrant workers.

This paper is organized as follows. Section 2 reviews the literature and Section 3 describes the data and methodology. Next, Section 4 presents our empirical results including the status of rural housing wealth between and within the villages at the rural-urban fringe. Section 5 tries to explain the formation of housing wealth differentiation. Lastly, we offer our discussion of policy implications and conclusions in Section 6.

\section{Literature Review}

Housing wealth is a main component of household wealth, possessing the dual functions of consumption and investment $[18,19]$, and acts as an indicator of household income and social status. Some researches show that housing wealth has significant impact on family entrepreneurship, consumption decision, labor mobility, education and marriage [20-24]. These studies focus on the relationships between housing inequality among residents and the rise in social inequality in many developing countries [25-27], especially focus on the influence of housing inequality on widening urban or rural inequality $[28,29]$. Housing wealth differentiation has commonly emerged in most countries worldwide, particularly in transitional, urbanizing countries such as those of Central and Eastern Europe [30]. Recently, an expanding gap between urban housing prices and income, and housing wealth differentiation in urban areas, has been well-documented [31-33]. Cities have gradually experienced housing-based social differentiation $[34,35]$. The growing housing value benefits the wealthier households in driving accumulation of more non-housing wealth than poorer ones, thereby widening wealth differentiation [36,37]. Housing wealth disparity between urban and rural areas has received more attention. Studies have explored the contribution of rural-urban housing inequality to overall housing wealth inequality, finding that the housing wealth gap between urban and rural areas was gradually widening [14]. Studies have shown that there were a portfolio of motives in the factors that determined housing demand for owner occupation and for renting out [19]. However, western studies were from the perspective of transferable dwellings and housing price appreciation as part of explanation for housing wealth accumulation. Goffette-Nagot and Sidibé estimated the impact of public housing, and found that households with high capacity regarded public housing as a springboard to homeownership by allowing them to save during their spell in public housing policy in order to buy a house [15].

However, issues of housing wealth differentiation in China are more complicated [16]. China has implemented a dual system of state-owned urban land and collectively-owned rural land [38]. It is different for urban and rural residents in their ways of accessing housing and the rights of livelihood security $[14,39,40]$. Since the reform of urban housing systems in the 1980s, the welfare housing allocation system characterized by courtyards has been transformed into a market-oriented housing system characterized by commercial housing [41]. Following the deconstruction of welfare housing policies and the development of market-oriented housing policies, housing differentiation and inequality in urban China have expanded rapidly [16,42]. In addition, housing wealth disparity has 
gradually emerged at the rural-urban fringe, stimulated by the development of an informal housing market $[5,43]$.

Many scholars have focused on housing wealth in urban areas [12,35]; some examine housing differentiation in urban villages [44], but there is far less literature focusing on housing wealth disparity in rural China. This is due to the following reasons:

First, China has implemented the policy of "one household owns one homestead" in rural villages. The differentiation of homesteads within a village is comparatively less, and disparities in building area are mainly determined by family economic conditions. Rural housing wealth is more equitable when disparity in family income within a village is lower. Related studies have shown that rural households with higher income and better social status usually have more building area and better housing conditions [45].

Second, the lagging marketization of rural housing as well as the difficulty in collecting micro data from the less developed and sparsely populated countryside have made it a challenge to study housing issues in rural China [14]. Previous studies of rural housing concentrated on micro case analyses based on a survey sample. The high cost of data collection, the limitations of survey samples, as well as the incompleteness and small amount of sample data, have made it hard to comprehensively explore the accumulation status of rural housing wealth and its differentiation. Furthermore, rural housing cannot be evaluated through the market due to the collective ownership of homesteads as part of the social welfare system. It is therefore hard to evaluate the wealth value of rural housing through transaction price, and a more effective method is to compare residential and building area.

While there are growing articles about housing wealth disparity and accumulation worldwide, most of them have focused on urban cities, and fewer studies are concerned about the formation of housing wealth disparity in rural areas.

\section{Data Source and Methodology}

\subsection{Data Source}

The rural housing data used in this study was derived from the comprehensive housing registration dataset conducted by the Shanghai Institute of Land Resource Survey in 2015-2017. To meet the requirements for the uniform survey as well as integrated registration of land and housing ownership, this survey covered all the houses and homesteads in the sampled villages, and created a town-level diagram of housing and land status including all the plots and households. It includes rural homestead boundaries, buildings, land use status, ownership certifications, and village-based homestead databases. To be specific, rural housing wealth and ownership information included were as follows: (1) ownership information, including the gender, age, householder, registration residence type of family members; (2) building information, including building area, floor area, building structure, building height, building layers, and structural information for main rooms, auxiliary rooms, sheds, as well as other information reflecting the housing accumulation process, such as initial construction year, years of expansions, and the numbers and areas of housing expansions.

For the quantitative analysis, this study adopted Kangqiao Town of Shanghai as a typical case of rural-urban fringes. The comprehensive housing registration information covered 3870 rural collective welfare houses distributed in 16 villages, with a total housing area of 905,414.36 $\mathrm{m}^{2}$ and a total homestead area of $501,914.18 \mathrm{~m}^{2}$. Comparing the survey data from Kangqiao Town, item by item, it was found that 378 of homesteads had been in service for more than 40 years, and they were constructed within the period of 1950s-1970s; some of them were even constructed in the early period of the Republic of China. These old houses, despite still being owned by someone, were basically idle or in a protected state, and they were not related to housing expansion. Rural houses constructed in the 40 years since the reform are still in use, part of the accumulation process, and there is a baseline to compare them. On that account, considering the statistical significance and comparability of research results, this paper only selected the 3492 rural houses constructed after 1978 for comparative analysis. 
Notably, a preliminary comparison revealed a phenomenon of "one household with several houses": 421 houses belonged to 199 rural households, meaning that each of these households had 2.12 rural houses. What needs to be noted, was that this study made no attempt to approach the problem of "one household with several houses" through data association, but focused on individual houses instead. If the phenomenon of "one household with several houses" was to be taken into account, the differentiation of rural housing wealth would be even more obvious. This can be further explored in future studies. In addition, this study confined its scope to self-owned rural collective welfare houses, and excluded commercial houses purchased in cities or towns by rural households at the rural-urban fringe after the accumulation of property income. Meanwhile, considering the non-tradability of rural housings and the implicit nature of housing values, this study only used house building area, homestead area, and other physical indicators to measure and identify rural housing wealth and differentiation status.

\subsection{Methodology}

\subsubsection{Measuring Disparities in Rural Housing Wealth}

This paper adopts the Gini coefficient (GC) to measure the distribution status of rural housing wealth. To be specific, the GC is used to measure the distribution equilibrium of rural housing wealth at the rural-urban fringe according to the following formula:

$$
G=1-\sum_{i=1}^{n}\left(X_{i}-X_{i-1}\right)\left(Y_{i}+Y_{i-1}\right)
$$

In Equation (1), $n$ denotes the number of rural houses; $X_{i}$ is the cumulative proportion of $i$ house in housing number; $Y_{i}$ is the cumulative proportion of $i$ house in housing wealth.

This paper further adopts the Theil coefficient to supplementally measure disparities in rural housing wealth. The advantage of the Theil Index $(T)$ is the ability to measure the contribution of within-village differences $\left(T_{W R}\right)$ and between-village differences $\left(T_{B R}\right)$ to the overall difference. The formula is:

$$
T_{d}=T_{B R}+T_{W R}=\sum_{i=1}^{m} h_{i} \log \frac{h_{i}}{p_{i}}+\sum_{i=1}^{m} h_{i}\left(\sum_{i=1}^{n} h_{g i} \log \frac{h_{g i}}{p_{g i}}\right)
$$

In Equation (2), $m$ refers to the number of villages, $h_{i}$ refers to the ratio of the building area in village $i$ to the total building area in the whole town. $p_{i}$ is the proportion of the households in village $i$ to the total households in whole town. $n$ refers to the number of households in village $i$, and $h_{g i}$ refers to the proportion of the building area of household $g$ in village $i$ to the total building area in village $i$. $p_{g i}$ is the proportion of the household $g$ to the total households in village $i$.

\subsubsection{Measuring the Accumulation of Rural Housing Wealth}

This paper adopts the decomposition method of the GC to investigate the impacts of housing structure, building density, extension, and reconstruction on housing wealth differentiation. Based on the function types (including main rooms, auxiliary rooms and sheds), building density (including residential land and building story), and extension and reconstruction (including initial area and extended area) of rural housing wealth, the GC can be decomposed to identify the key factors affecting housing wealth status and their degree of contribution. The decomposition of GC obeys the following principle [46]:

$Y_{0}=\left(Y_{01}, Y_{02}, \ldots, Y_{0 n}\right)$ is an $n$-dimensional row vector in which $Y_{0 i}$ denotes the wealth stock of $i$ house. After classifying total housing wealth into $k$ types based on housing function types, building 
density, and extension conditions, the $k$ type of housing wealth can also be defined by an $n$-dimensional row vector, $Y_{k}=\left(Y_{k 1}, Y_{k 2}, \ldots, Y_{k n}\right)$. In this case, the overall GC can be decomposed as follows:

$$
G_{0}=\sum_{k} S_{k} G_{k}^{\prime}
$$

In Equation (3), $S_{k}$ is the share of the $k$ type of housing wealth in total housing wealth; $G_{k}{ }^{\prime}$ denotes the concentration ratio (pseudo-Gini coefficient) of the $k$ type to housing wealth (Concentration ratio is the GC of $k$ type of housing assets in ascending order of total housing assets. If $k$ type of housing assets is mainly concentrated in a group with low total housing assets, the concentration ratio of this type may be negative). If the contribution of $k$ type to the GC is greater than its share in total housing wealth, this type of housing wealth will widen the accumulation inequality of total housing wealth. That is to say, a rise in the proportion of this type in total housing wealth will increase the GC of total housing wealth.

The degree of contribution of the $k$ type of housing wealth to the differentiation of total housing wealth can be denoted by $v_{k}$ :

$$
v_{k}=S_{k} \bar{G}_{k} / G_{0}
$$

If the variation amplitude of $k$ type of housing wealth is $e$ :

$$
Y_{k}(e)=(1+e) Y_{k}
$$

The marginal impact of the $k$ type on the accumulation inequality of total housing wealth becomes:

$$
\frac{\partial G_{0}}{\partial e}=S_{k}\left(\bar{G}_{k}-G_{0}\right)
$$

When the variation of the $k$ type of housing wealth is $e Y_{k}$, the variation of the GC of total housing wealth is $S_{k}\left(G_{k}{ }^{\prime}-G_{0}\right)$, in which the GC of elasticity is:

$$
\lambda_{k}=\frac{1}{G_{0}} \frac{\partial G_{0}}{\partial e}=S_{k}\left(\frac{\bar{G}_{k}}{G_{0}}-1\right)
$$

This means that when the $k$ type of housing wealth increases by $1 \%$, the GC of rural housing wealth increases by $\lambda_{k}$.

\section{Status and Accumulation of Rural Housing Wealth in Kangqiao Town}

The 3492 self-contained rural houses were constructed in 1978-2017 in Kangqiao Town, Pudong New Area. In specific, 971 homes in the whole sample had been extended or reconstructed, while 2521 had not. The rural houses of Kangqiao Town had an initial building area of $194.54 \mathrm{~m}^{2}$ on average $\left(\right.$ median $\left.=203.24 \mathrm{~m}^{2}\right)$, and an initial homestead area of $99.22 \mathrm{~m}^{2}\left(\right.$ median $\left.=101.62 \mathrm{~m}^{2}\right)$. The fact that mean and median were very close suggests the initial housing wealth, characterized by building area and floor area, was basically uniform among rural houses. After experiencing a total of 1466 actions of extension and reconstruction in 1978-2008, average rural building area increased to $241.09 \mathrm{~m}^{2}$ per house, and average rural floor area increased to $131.72 \mathrm{~m}^{2}$ per house, affecting the equilibrium status of rural housing wealth (Figure 1). Based on housing function types, rural houses are usually classified into main rooms, auxiliary rooms and sheds. To be specific, main rooms are formal rooms that are constructed on the approved homestead for household use, such as living rooms and bedrooms; auxiliary rooms are rooms that are constructed around main rooms for storing grains and production tools, such as separate kitchens and utility rooms; sheds are temporary ancillary facilities, such as stables used to raise livestock and covered frames used to grow vegetables. Comparing housing composition before and after extension and reconstruction (Figure 2 and Table A1), at initial construction, the main rooms of rural houses accounted for an average of $88.61 \%$ and $82.61 \%$ of the total building area and 
total floor area, respectively. Main rooms occupied stable proportions in the composition of rural houses, and auxiliary rooms only played auxiliary roles; housing composition matched the demands of rural production. However, in the past 40 years, extension and reconstruction have reduced the proportions of building area and floor area for main rooms, while increasing those for auxiliary rooms. In other words, the distribution of rural housing wealth has changed the balance by "narrowing main rooms, expanding auxiliary rooms".

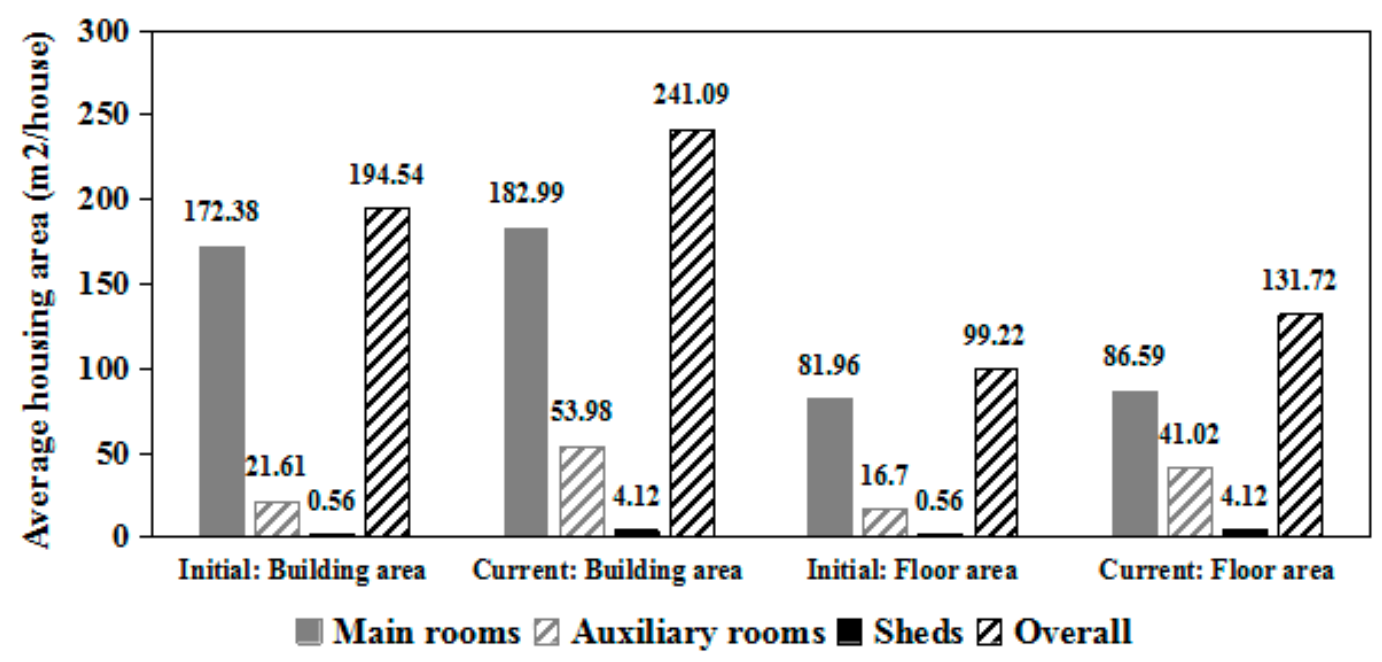

Figure 1. Comparison of rural housing wealth before and after extension and reconstruction in the study area.
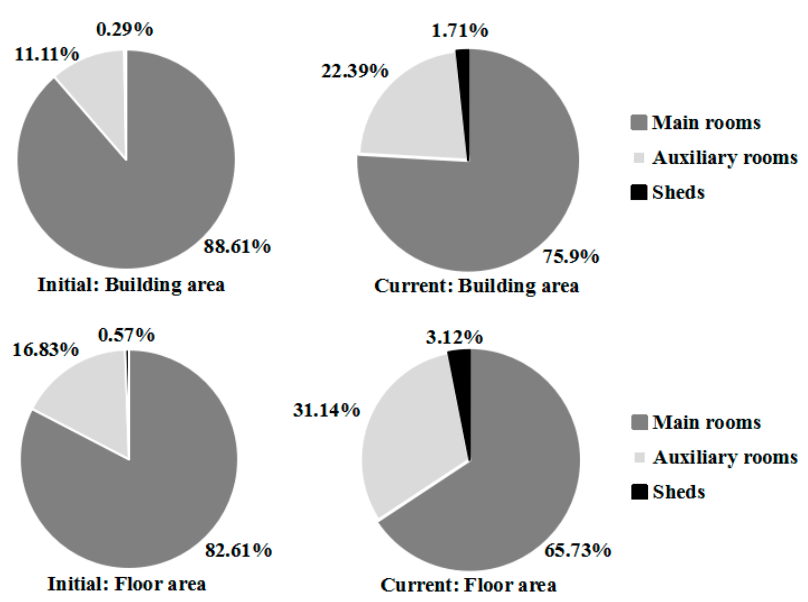

Figure 2. Comparison of rural housing composition before and after extension and reconstruction in the study area.

\subsection{Status of Housing Wealth Among Rural Households in Kangqiao Town}

The frequent extension of auxiliary rooms supported a continuous increase in rural housing wealth. The extension and reconstruction of auxiliary rooms increased the total building area and total floor area by $113,045.15 \mathrm{~m}^{2}$ and $84,938.6 \mathrm{~m}^{2}$, respectively, accounting for $69.55 \%$ and $74.84 \%$ of increased housing wealth. The extension of auxiliary room has become a main way to increase the rural housing wealth at the rural-urban fringe. Some villagers, in order to grow their housing wealth, have even reconstructed their auxiliary rooms without authorization. Seen from the comparison of average housing wealth by group with and without extension and reconstruction (Figure 3), for extended and reconstructed samples, the average building area of auxiliary rooms and sheds significantly increased by $53.18 \mathrm{~m}^{2}$ and $11.93 \mathrm{~m}^{2}$, respectively, however, extension and reconstruction did not cause any obvious difference in the average housing area of main rooms. The average floor area of main rooms 
for samples without extension was slightly higher than that for samples with extension. To some extent, this indicates that, regardless of extension and reconstruction, rural houses had the same size of main rooms; later on, with the improvement of economic conditions, households whose building area and floor area were small tend to extend their auxiliary rooms, thus increasing housing wealth and meeting a balance of needs.
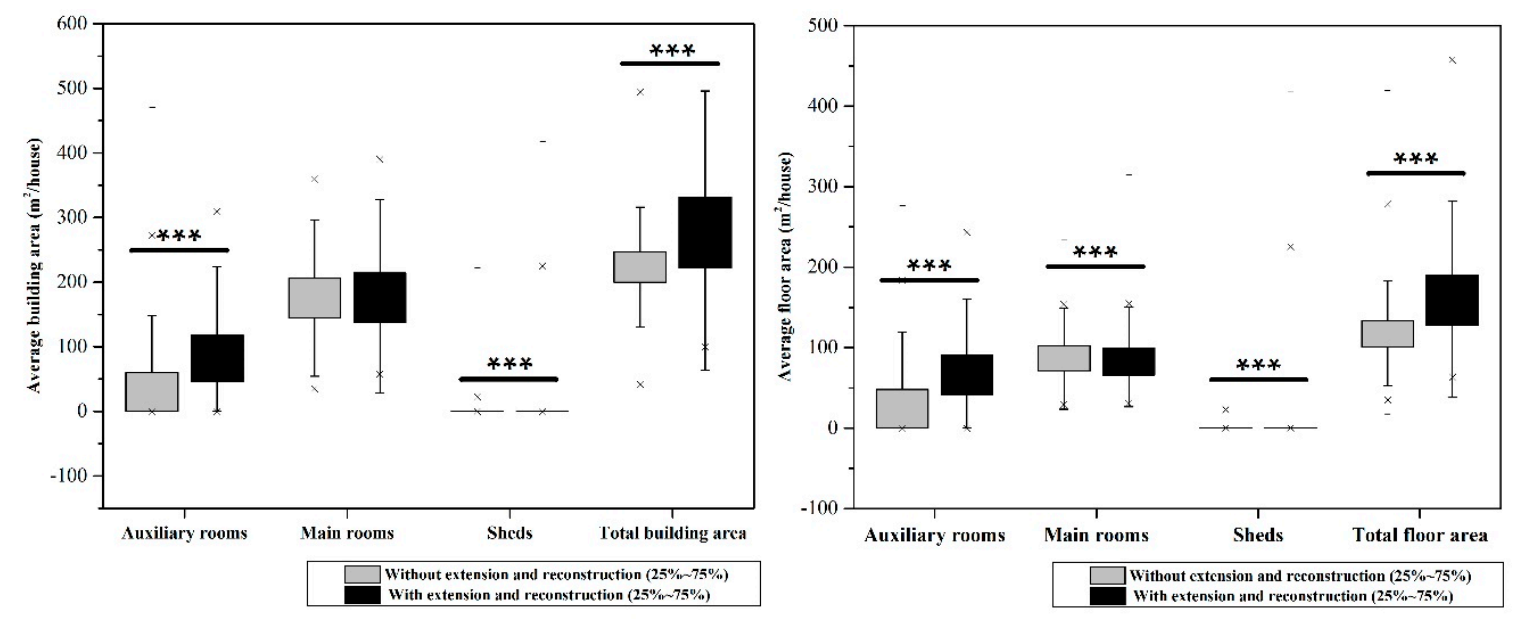

Figure 3. Comparison of rural housing wealth by group with and without extension and reconstruction in the study area. ${ }^{* * *} p<0.01$.

\subsubsection{Status of Rural Housing Wealth by Area Groups}

Housing wealth disparity between groups has preliminarily taken shape, and the proportions of housing extension and reconstruction were high at the two extremes $\left(<150 \mathrm{~m}^{2}\right.$ and $\left.\geq 350 \mathrm{~m}^{2}\right)$. Based on the mean and standard deviation, this study divided these rural houses into four groups (i.e., $<150 \mathrm{~m}^{2}, 150-250 \mathrm{~m}^{2}, 250-350 \mathrm{~m}^{2}$, and $\geq 350 \mathrm{~m}^{2}$ ) according to initial building area, aiming to compare them in terms of the extension and reconstruction status as well as the mobility of housing wealth (Figure 4). Upon initial construction, rural house size was in a normal distribution. After extension and reconstruction, the proportions of the group with housing areas of 250-350 $\mathrm{m}^{2}$ and the group with housing areas of $\geq 350 \mathrm{~m}^{2}$ significantly increased; those of the group with housing areas of $<150 \mathrm{~m}^{2}$ and the group with housing areas of $150-250 \mathrm{~m}^{2}$ dropped abruptly. Rural housing wealth accumulated rapidly at the lowest cost, thus gradually widening disparities in rural housing wealth. This was also confirmed by the change in rural housing area among the four groups (Figure 5 and Table A2). After extension and reconstruction, both building area per house and floor area per house significantly increased in the four groups, especially in the two ends $\left(<150 \mathrm{~m}^{2}\right.$ and $\left.\geq 350 \mathrm{~m}^{2}\right)$. This suggests that disequilibrium in rural housing wealth had preliminarily taken shape between groups; and that, after the operational functions of rural housing wealth became explicit, the group with housing areas of $<150 \mathrm{~m}^{2}$ and the group with housing areas of $\geq 350 \mathrm{~m}^{2}$ both had a strong motivation to increase their housing wealth, thus presenting an obvious variation trend at the two ends. By means of extension and reconstruction, rural households in the group with housing areas of $<150 \mathrm{~m}^{2}$ increased their wealth to improve their housing conditions and narrow the gap with the average housing wealth level of their village; in contrast, those in the group with housing areas of $\geq 350 \mathrm{~m}^{2}$ continued to widen the gap with the average housing wealth level by taking advantage of their economic status, social status, and other relative advantages after increasing their housing wealth and property incomes. 


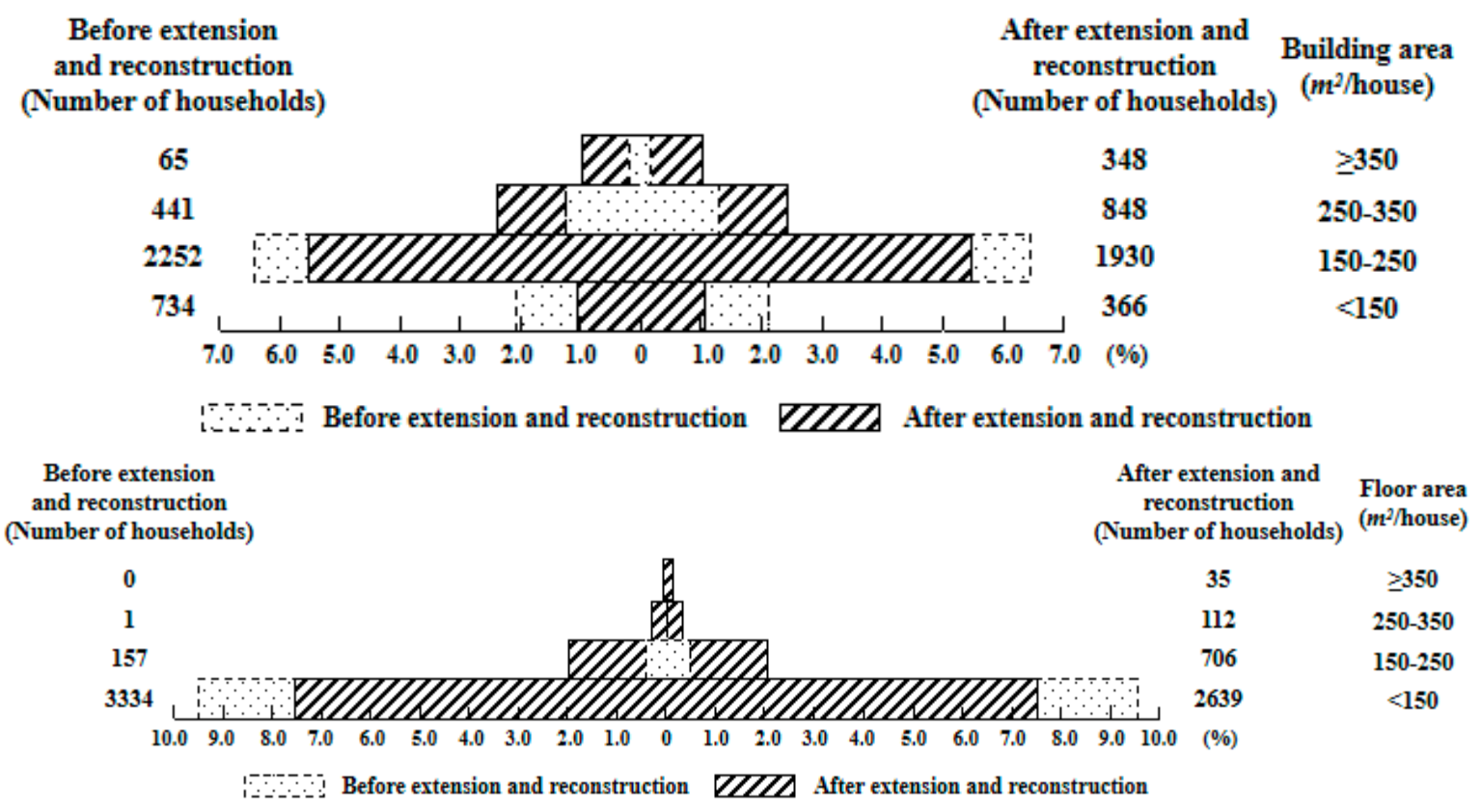

Figure 4. The size distribution of rural housing wealth in the study area.

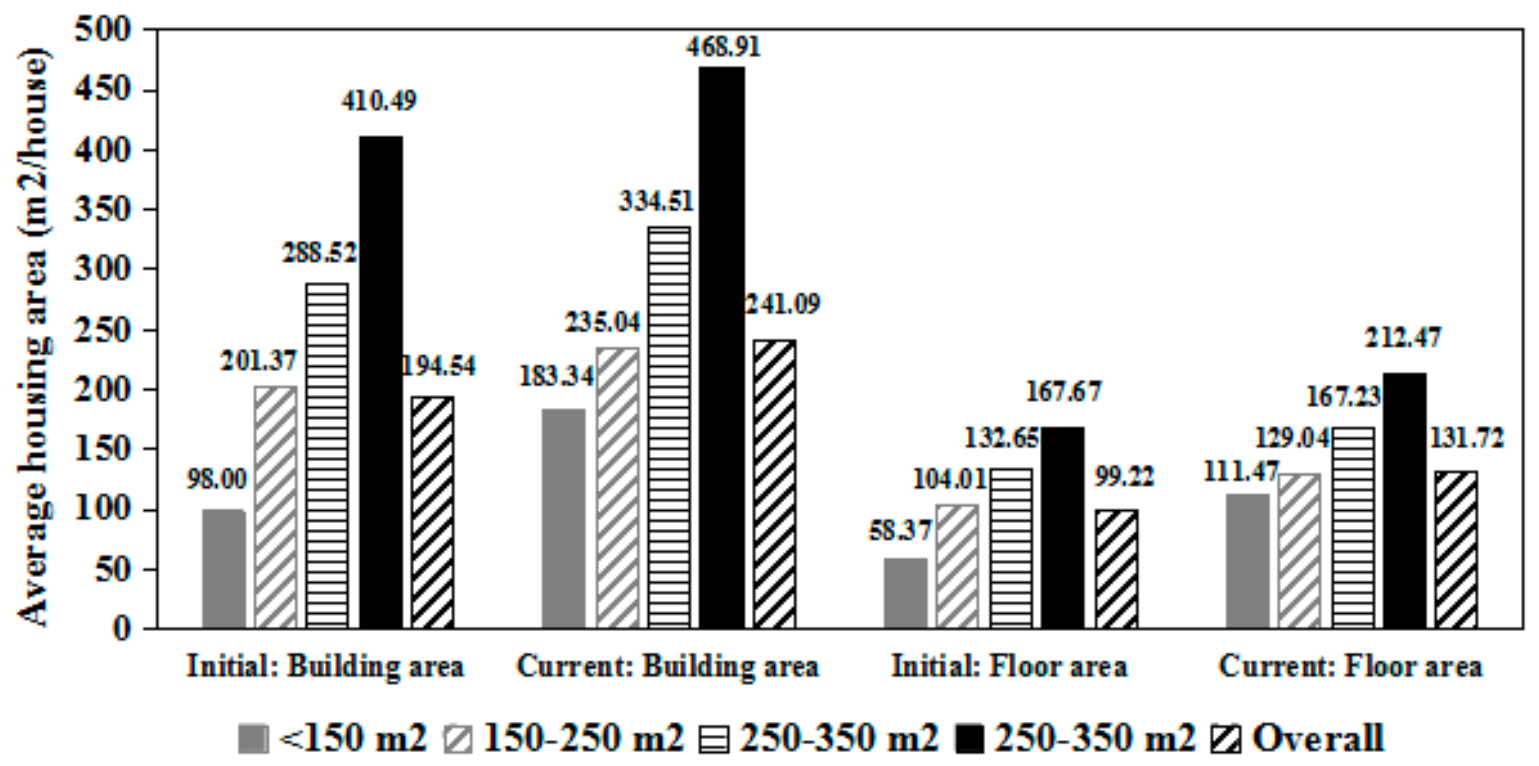

Figure 5. Comparison of rural housing wealth by area groups before and after extension and reconstruction in the study area.

Based on the above analysis, this study compared extended and reconstructed houses in details (Table 1), and found that building area and floor area had increased by $106.64 \mathrm{~m}^{2} /$ house and $76.65 \mathrm{~m}^{2} /$ house, respectively. To be specific, the group with housing areas of $<150 \mathrm{~m}^{2}$ and the group with housing areas of $\geq 350 \mathrm{~m}^{2}$ witnessed the largest increments through extension and reconstruction, which exceeded the average increment. As high as $44.28 \%$ of rural houses in the group with housing areas of $<150 \mathrm{~m}^{2}$ and $33.85 \%$ of those in the group with housing areas of $\geq 350 \mathrm{~m}^{2}$ had been extended and reconstructed, and they realized the improvement of housing conditions and the accumulation of housing wealth through extension and reconstruction. 
Table 1. Comparison of rural housing change by area groups for those taking part in extension and reconstruction in the study area.

\begin{tabular}{|c|c|c|c|c|c|c|c|c|}
\hline \multirow{3}{*}{$\underset{\left(\mathrm{m}^{2} / \text { House }\right)}{\text { Group }}$} & \multicolumn{4}{|c|}{ Initial Area } & \multicolumn{4}{|c|}{$\begin{array}{c}\text { Accumulative Area after } \\
\text { Extension and Reconstruction }\end{array}$} \\
\hline & \multicolumn{2}{|c|}{ Building Area } & \multicolumn{2}{|c|}{ Floor Area } & \multicolumn{2}{|c|}{ Building Area } & \multicolumn{2}{|c|}{ Floor Area } \\
\hline & $\begin{array}{l}\text { Summary } \\
\left(\mathrm{m}^{2}\right)\end{array}$ & $\begin{array}{c}\text { Mean } \\
\left(\mathrm{m}^{2} / \text { house) }\right.\end{array}$ & $\begin{array}{l}\text { Summary } \\
\left(\mathrm{m}^{2}\right)\end{array}$ & $\begin{array}{c}\text { Mean } \\
\left(\mathrm{m}^{2} / \text { house) }\right.\end{array}$ & $\begin{array}{c}\text { Summary } \\
\left(\mathrm{m}^{2}\right)\end{array}$ & $\begin{array}{c}\text { Mean } \\
\left(\mathrm{m}^{2} / \text { house) }\right.\end{array}$ & $\begin{array}{l}\text { Summary } \\
\left(\mathrm{m}^{2}\right)\end{array}$ & $\begin{array}{c}\text { Mean } \\
\left(\mathrm{m}^{2} / \text { House }\right)\end{array}$ \\
\hline$<150 \mathrm{~m}^{2}$ & $31,252.5$ & 96.2 & $17,950.4$ & 55.2 & $80,225.0$ & 246.9 & $48,489.2$ & 149.2 \\
\hline $150-250 \mathrm{~m}^{2}$ & $98,311.4$ & 197.4 & $50,562.8$ & 101.5 & $141,472.9$ & 284.1 & $85,127.4$ & 170.9 \\
\hline $250-350 \mathrm{~m}^{2}$ & $35,950.4$ & 285.3 & $16,751.9$ & 133.0 & $44,928.4$ & 356.6 & $24,098.7$ & 191.3 \\
\hline$\geq 350 \mathrm{~m}^{2}$ & 8989.6 & 408.6 & 3750.4 & 170.5 & $11,430.7$ & 519.6 & 5727.9 & 260.4 \\
\hline Overall & $174,504.0$ & 179.7 & $89,015.4$ & 91.7 & $278,057.0$ & 286.4 & $163,443.1$ & 168.3 \\
\hline
\end{tabular}

\subsubsection{Status of Rural Housing Wealth from 1978 to 2017}

The year of house extension and reconstruction were concentrated in the period of 1978-2008, and this phenomenon has basically been inhibited in recent decades. Since the reform and opening-up, the number and area of rural houses have seen a rapid increase with the growth of farmers' income, thus realizing "Home Ownership" for all rural households (Table A3). Since these rural houses were constructed in 1978-1987 and 1988-1997, there have been as many as 659 and 252 extension and reconstruction occurrences respectively, which accounts for $67.84 \%$ and $25.95 \%$ of the cumulative occurrences of extension and reconstruction. The average areas of the samples increased by $71.83 \mathrm{~m}^{2}$ and $58.82 \mathrm{~m}^{2}$ during these two periods. Since 2008, the town has seen only three occurrences of extension and reconstruction, suggesting that spatial planning for land resources and explicit regulation of house construction at the rural-urban fringe in Shanghai has been strengthened, and that rural house extension as well as reconstruction has been effectively controlled and restrained.

\subsection{Status of Rural Housing Wealth at Village-Level in Kangqiao Town}

Rural housing wealth was uniform at the village-level, but a preliminary differentiation emerged following initial construction. The rural housing status of 16 villages in Kangqiao Town has been analyzed by collecting several data. Clearly, there were differences in rural housing wealth and accumulation process among these villages (see Table 2). The average building area for five villages (i.e., Huojian, Huaqiang, Yanbei, Taiping and Zitong) was 7-22\% higher than the mean level of whole town. The average building area for another five villages (i.e., Baiqu, Dieqiao, Tangxiang, Xinmiao and Yingfang) was equivalent to the mean level of Kangqiao Town. Those for six other villages (i.e., Hehe, Mianqing, Rennan, Shimen, Xiulong and Yannan) was 5-20\% lower than the mean level of the town. Relative to existing status, rural houses in various villages had a low degree of differentiation at initial construction. The initial house area for nine villages (i.e., Baiqu, Hehe, Huaqiang, Taiping, Tangxiang, Xiulong, Yannan, Yingfang and Rennan) was close to the mean level. The initial house area for four villages (i.e., Mianqing, Dieqiao, Shimen and Zitong) was lower than the mean level. The initial house area for three villages (i.e., Huojian, Xinmiao and Yanbei) was 8-22\% higher than the mean level. In the past four decades, extension and reconstruction increased the average building area by $46.55 \mathrm{~m}^{2} /$ house in the town. To be precise, auxiliary rooms' extension and reconstruction accounted for $69.55 \%$ of the overall extended area. Auxiliary rooms' extension accounted for $56-91 \%$ in Baiqu, Huaqiang, Mianqing, Rennan, Xinmiao, Yanbei, Xiulong, Yannan, Yingfang and Zitong; in Dieqiao, Shimen, Tangxiang and Huojian, main rooms' extension and reconstruction played a dominant role. 
Table 2. Rural housing wealth by villages before and after reconstruction in the study area.

\begin{tabular}{|c|c|c|c|c|c|c|c|c|c|c|c|c|c|}
\hline \multirow{2}{*}{ Villages } & \multirow{2}{*}{$\begin{array}{l}\text { Houses } \\
\text { Number }\end{array}$} & \multicolumn{4}{|c|}{ Initial Housing Composition (m²/House) } & \multicolumn{4}{|c|}{$\begin{array}{l}\text { Housing Composition after Extension and } \\
\text { Reconstruction }\left(\mathrm{m}^{2} / \text { House }\right)\end{array}$} & \multicolumn{4}{|c|}{ Change $\left(\mathrm{m}^{2} /\right.$ House) } \\
\hline & & $\begin{array}{l}\text { Main } \\
\text { Rooms }\end{array}$ & $\begin{array}{l}\text { Auxiliary } \\
\text { Rooms }\end{array}$ & Sheds & Subtotal & $\begin{array}{l}\text { Main } \\
\text { Rooms }\end{array}$ & $\begin{array}{l}\text { Auxiliary } \\
\text { Rooms }\end{array}$ & Sheds & Subtotal & $\begin{array}{l}\text { Main } \\
\text { Rooms }\end{array}$ & $\begin{array}{l}\text { Auxiliary } \\
\text { Rooms }\end{array}$ & Sheds & Over-all \\
\hline Baiqu & 117 & 164.3 & 33.9 & 0.1 & 198.3 & 164.5 & 77.9 & 3.0 & 245.4 & 0.3 & 44 & 2.9 & 47.1 \\
\hline Dieqiao & 66 & 152.0 & 19.9 & 0 & 172.0 & 215.4 & 31.1 & 0 & 246.4 & 63.3 & 11.1 & 0 & 74.5 \\
\hline Hehe & 115 & 203.1 & 0 & 0 & 203.1 & 203.1 & 0 & 0 & 203.1 & 0 & 0 & 0 & 0 \\
\hline Huaqiang & 301 & 161.2 & 42.8 & 0 & 204.1 & 162.2 & 118.3 & 0 & 280.4 & 1.0 & 75.4 & 0 & 76.4 \\
\hline Huojian & 90 & 206.2 & 31.1 & 0 & 237.3 & 237.5 & 55.6 & 0 & 293.1 & 31.3 & 24.5 & 0 & 55.8 \\
\hline Mianqing & 430 & 131.5 & 22.2 & 0.1 & 153.8 & 140.0 & 52.2 & 0.1 & 192.4 & 8.5 & 30.0 & 0 & 38.6 \\
\hline Rennan & 221 & 163.8 & 28.5 & 0 & 192.3 & 169.2 & 55.3 & 0 & 224.6 & 5.5 & 26.8 & 0 & 32.2 \\
\hline Shimen & 104 & 153.6 & 26.2 & 0 & 179.8 & 190.1 & 38.2 & 0 & 228.3 & 36.5 & 12.1 & 0 & 48.6 \\
\hline Taiping & 480 & 184.8 & 9.5 & 3.0 & 197.3 & 203.1 & 39.5 & 27.4 & 270.0 & 18.3 & 30.1 & 24.4 & 72.7 \\
\hline Tangxiang & 178 & 178.0 & 23.1 & 0 & 201.1 & 201.1 & 46.1 & 0 & 247.2 & 23.1 & 23.1 & 0 & 46.1 \\
\hline Xinmiao & 219 & 168.7 & 40.9 & 0 & 209.6 & 169.4 & 78.0 & 0 & 247.4 & 0.7 & 37.2 & 0 & 37.8 \\
\hline Xiulong & 353 & 194.2 & 6.2 & 0.04 & 200.5 & 203.7 & 21.3 & 0.04 & 225.0 & 9.5 & 15.1 & 0 & 24.6 \\
\hline Yanbei & 71 & 176.4 & 36.3 & 6.3 & 219.0 & 178.2 & 93.9 & 11.7 & 283.7 & 1.7 & 57.6 & 5.4 & 64.8 \\
\hline Yannan & 252 & 183.0 & 17.4 & 0 & 200.4 & 187.6 & 41.2 & 0 & 228.7 & 4.6 & 23.8 & 0 & 28.4 \\
\hline Yingfang & 362 & 190.2 & 13.4 & 0 & 203.5 & 198.2 & 43.2 & 0 & 241.4 & 8.1 & 29.8 & 0 & 37.9 \\
\hline Zitong & 133 & 151.5 & 32.5 & 0 & 183.9 & 155.4 & 102.5 & 0 & 257.8 & 3.9 & 70.0 & 0 & 73.9 \\
\hline Overall & 3492 & 172.4 & 21.6 & 0.6 & 194.5 & 183.0 & 54.0 & 4.1 & 241.1 & 10.6 & 32.4 & 3.6 & 46.6 \\
\hline
\end{tabular}




\section{Disparities of Rural Housing Wealth by Villages}

Difference coefficient of rural housing wealth in urban villages or suburban villages was obviously higher than in the outer suburbs. The difference coefficient of rural housing wealth at village-level has been compared before and after extension and reconstruction (see Figures 6 and 7). The GC of rural housing wealth was 0.1974 in Kangqiao Town, which testified to the current distribution equilibrium of rural housings at the rural-urban fringe. However, compared to the GC for the new planned village, Hehe (0.0073), which implied an absolutely equal status, this coefficient had already shown some preliminary differentiation. This coefficient was also greater than the GC based on the initial area (0.1861). This suggests that rural housing wealth has shown a preliminary differentiation inside and between villages at the rural-urban fringe after accumulation, and transformed to an overall equilibrium with slight differentiation. The change in Theil coefficient before and after extension and reconstruction also clarified this conclusion.

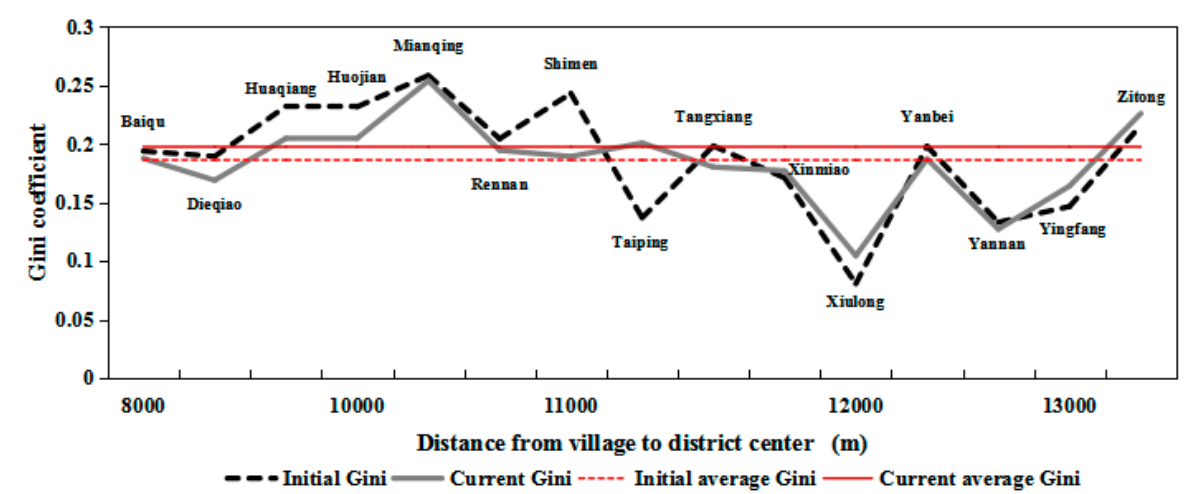

Figure 6. Comparative GC (Gini coefficient) of rural housing wealth by villages before and after extension and reconstruction in the study area.

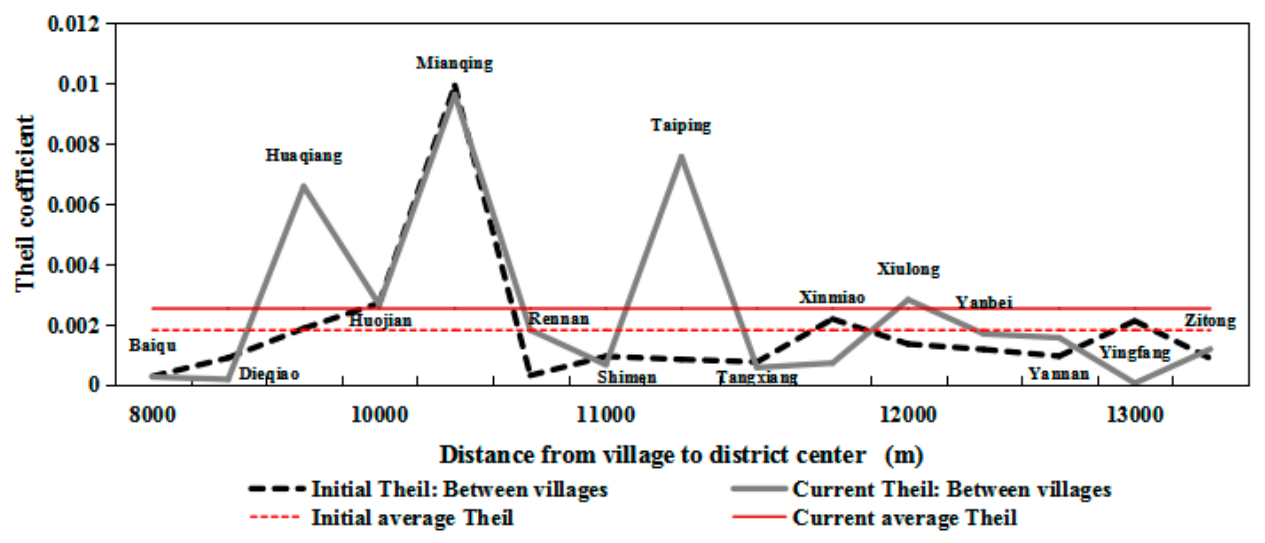

Figure 7. Comparative Theil coefficient of rural housing wealth by villages before and after extension and reconstruction in the study area.

Furthermore, seen from the difference coefficient of rural housing wealth for each village, the GC of the building area exceeded the average GC in five villages, i.e., Taiping, Huaqiang, Huojian, Mianqing and Zitong; and the Theil coefficient of the building area exceeded the average level in four villages, i.e., Taiping, Huangqiang, Huojian and Mianqing. These villages' rural housing wealth was relatively equal, but a polarization has been taking shape. The GC of the building area was less than the average in 11 villages (Xiulong, Yanbei and so forth); and these villages' Theil coefficient was also less than average. In these villages, rural housing wealth was in distribution equilibrium. As revealed by further analysis of location conditions, on the one hand, Huaqiang, Huojian, Mianqing and Taiping are adjacent to the center of Pudong New Area. They are equipped with an obvious location advantage and 
enjoy convenient access to the transportation infrastructure as well as public service facilities in district center. Moreover, their housing functions have gradually transformed to serve commercial, industrial, and many other operational functions, which are driven by commercial housing markets and the industrial economies; in particular, the living demands of migrant workers have resulted in active informal rural housing markets. Induced by the non-agricultural construction and land marketization, the housing economic functions in suburban villages have become explicit, and some villagers have chosen to directly invest in extension and reconstruction for increasing their housing property income and growing their housing wealth. In addition, given that these villages are adjacent to district center, villagers have more non-agricultural livelihood sources, higher economic income, and more sufficient social strength and capitals; with which they can further reconstruct existing auxiliary rooms and sheds, thereby accumulating housing wealth. On the other hand, as for Xiulong and other villages where the GC of the building area was less than the average level, their Theil coefficient was also lower than the average level. These were outer suburban villages at the rural-urban fringe, and were far away from the center of Pudong New Area. The housing property function in these villages has not yet fully manifested, and rural houses mainly serve production and living purposes, so the frequency and area of extension and reconstruction are both lower in these villages than those villages adjacent to district center.

\subsection{Accumulation of Rural Housing Wealth in Kangqiao Town}

The GC and its decomposition were used to analyze the accumulation of rural housing wealth and wealth differentiation from the perspective of house structure and the extension process.

\subsubsection{Impacts of Housing Structure on Housing Wealth Differentiation}

There was a significant differentiation in rural auxiliary rooms, which caused the housing wealth disparities among villages. The GC and its decomposition for the rural housing wealth at village-level have been listed in Kangqiao Town based on the function of housing (Table 3). In Kangqiao Town, main rooms had a GC of 0.1192 , as well as an elasticity coefficient of -0.3008 . This suggests that the main rooms' building areas are absolutely equal. Auxiliary rooms had a GC of 0.4174 , and an elasticity coefficient of 0.2497 . This suggests that the disequilibrium status was obvious, and that auxiliary rooms were the key to the differentiation of rural housing wealth. Hehe, whose rural houses were constructed according to unified standards, basically had the same building area without auxiliary rooms and sheds. In contrast, there were significant differences among the other 15 villages in GC and composition. The GC of main rooms in various villages were uniformly less than 0.2 , suggesting that the disparities of main rooms were small. However, there were significant differences in GC of auxiliary rooms among villages. Auxiliary rooms' GC were greater than 0.4 in Mianqing, Taiping, Xiulong, Yannan and Yingfang. This suggests that these villages showed significant differences in auxiliary room space, and that the frequent extension and reconstruction of auxiliary rooms further widened their housing differentiation. Rural sheds had a GC of 0.9633 , but they only contributed $6.82 \%$ of the GC for overall rural housing wealth, thus having little effect on housing wealth differentiation. The main reason was that only five villages had sheds, accounting for $1.71 \%$ of total housing wealth, so they failed to cause any substantial variation in the GC of rural housing wealth. 
Table 3. GC and its decomposition of rural housing wealth by villages in the study area.

\begin{tabular}{|c|c|c|c|c|c|c|c|c|c|c|}
\hline \multirow[b]{2}{*}{ Villages } & \multirow[b]{2}{*}{ Subtotal } & \multicolumn{3}{|c|}{ Main Rooms } & \multicolumn{3}{|c|}{ Auxiliary Rooms } & \multicolumn{3}{|c|}{ Sheds } \\
\hline & & Share $(\%)$ & $\begin{array}{l}\text { Concentration Rate/ } \\
\text { Gini Coefficient }\end{array}$ & $\begin{array}{c}\text { Elasticity } \\
\text { Coefficient }\end{array}$ & Share (\%) & $\begin{array}{l}\text { Concentration Rate/ } \\
\text { Gini Coefficient }\end{array}$ & $\begin{array}{c}\text { Elasticity } \\
\text { Coefficient }\end{array}$ & Share (\%) & $\begin{array}{l}\text { Concentration Rate/ } \\
\text { Gini Coefficient }\end{array}$ & $\begin{array}{c}\text { Elasticity } \\
\text { Coefficient }\end{array}$ \\
\hline Baiqu & 0.1875 & 67.04 & 0.1705 & -0.0611 & 31.76 & 0.2248 & 0.0630 & 0.1570 & -0.0020 & 0.1570 \\
\hline Dieqiao & 0.1688 & 87.39 & 0.1826 & 0.0714 & 12.61 & 0.0732 & -0.0714 & & & \\
\hline Hehe & 0.0073 & 100.00 & 0.0073 & 0.0000 & & & & & & \\
\hline Huaqiang & 0.2046 & 57.84 & 0.1671 & -0.1060 & 42.16 & 0.2560 & 0.1060 & & & \\
\hline Huojian & 0.2047 & 81.03 & 0.1992 & -0.0215 & 18.97 & 0.2279 & 0.0215 & & & \\
\hline Mianqing & 0.2537 & 72.80 & 0.1898 & -0.1833 & 27.15 & 0.4246 & 0.1829 & 0.4442 & 0.0004 & 0.4442 \\
\hline Rennan & 0.1944 & 75.37 & 0.1669 & -0.1066 & 24.63 & 0.2786 & 0.1066 & & & \\
\hline Shimen & 0.1891 & 83.26 & 0.1960 & 0.0300 & 16.74 & 0.1552 & -0.0300 & & & \\
\hline Taiping & 0.2006 & 75.23 & 0.0469 & -0.5763 & 14.63 & 0.6354 & 0.3171 & 0.7135 & 0.2592 & 0.7135 \\
\hline Tangxiang & 0.1801 & 81.34 & 0.1595 & -0.0928 & 18.66 & 0.2696 & 0.0928 & & & \\
\hline Xinmiao & 0.1770 & 68.46 & 0.1382 & -0.1502 & 31.54 & 0.2613 & 0.1502 & & & \\
\hline Xiulong & 0.1045 & 90.52 & 0.0343 & -0.6079 & 9.46 & 0.7744 & 0.6067 & 0.8385 & 0.0011 & 0.8385 \\
\hline Yanbei & 0.1870 & 62.79 & 0.1480 & -0.1311 & 33.08 & 0.2075 & 0.0363 & 0.6168 & 0.0948 & 0.6168 \\
\hline Yannan & 0.1271 & 82.00 & 0.0503 & -0.4959 & 18.00 & 0.4773 & 0.4959 & & & \\
\hline Yingfang & 0.1639 & 82.13 & 0.0810 & -0.4154 & 17.87 & 0.5448 & 0.4154 & & & \\
\hline Zitong & 0.2258 & 60.25 & 0.1722 & -0.1431 & 39.75 & 0.3071 & 0.1431 & & & \\
\hline Overall & 0.1974 & 75.90 & 0.1192 & -0.3008 & 22.39 & 0.4174 & 0.2497 & 1.71 & 0.7880 & 0.0511 \\
\hline
\end{tabular}




\subsubsection{Impacts of the Extension Process on Housing Wealth Differentiation}

The frequent extension and reconstruction of auxiliary rooms provided a path directly leading to preliminary differentiation of rural housing wealth in Kangqiao Town. Auxiliary room extension and reconstruction is a main way to increase rural housing wealth. As indicated by above analysis, the main method of extension was to dismantle one-story auxiliary rooms and build two-story or higher ones instead (77.35\%). The decomposition of the GC has been illustrated based on initial housing area and extension of housing area (Table 4). Clearly, the building area that increased through extension and reconstruction constituted the primary cause of the preliminary source of housing differentiation. The contribution rate of GC for initial housing area was only $25.60 \%$, while that for extension area was as high as $74.40 \%$. In addition, the extended and reconstructed area had a GC of 0.4930 , suggesting that there were significant differences in extension area. The Gini elasticity coefficient of extended and reconstructed area was positive, meaning that the proportionate increase in it would further widen the differentiation of total housing wealth. A continuous increase occurred in some villages, gradually widening the inequality in rural housing wealth. In particular, in four villages (i.e., Huojian, Mianqing, Taiping and Shimen), the effect of extension and reconstruction in widening housing inequality was obviously strong. As a result, the GC of housing wealth was relatively high in these villages.

Table 4. GC of rural housing wealth and its extension decomposition by villages in the study area.

\begin{tabular}{ccccccc}
\hline & & \multicolumn{3}{c}{ Initial Area } & \multicolumn{2}{c}{ Extension and Reconstruction Area } \\
\cline { 2 - 6 } Villages & Total & Share (\%) & $\begin{array}{c}\text { Concentration Rate/ } \\
\text { Gini Coefficient }\end{array}$ & $\begin{array}{c}\text { Elasticity } \\
\text { Coefficient }\end{array}$ & Share (\%) & $\begin{array}{c}\text { Concentration Rate/ } \\
\text { Gini Coefficient }\end{array}$ \\
$\begin{array}{ccccccc}\text { Elasticity } \\
\text { Coefficient }\end{array}$ \\
\hline Baiqu & 0.1875 & 80.80 & 0.0734 & -0.1974 & 19.20 & 0.1970 \\
Dieqiao & 0.1688 & 69.79 & 0.0492 & -0.3948 & 30.21 & 0.1974 \\
Hehe & 0.0073 & 100.00 & 0.0073 & 0.0000 & & 0.3948 \\
Huaqiang & 0.2046 & 72.76 & 0.0855 & -0.2633 & 27.24 & 0.2635 \\
Huojian & 0.2047 & 80.97 & 0.1464 & -0.1588 & 19.03 & 0.3341 \\
Mianqing & 0.2537 & 79.96 & 0.1089 & -0.3084 & 20.04 & 0.4501 \\
Rennan & 0.1944 & 85.65 & 0.1076 & -0.2510 & 14.35 & 0.4185 \\
Shimen & 0.1891 & 78.73 & 0.0958 & -0.3204 & 21.27 & 0.4049 \\
Taiping & 0.2006 & 73.07 & -0.0224 & -0.8289 & 26.93 & 0.6794 \\
Tangxiang & 0.1801 & 81.34 & 0.0237 & -0.5765 & 18.66 & 0.3084 \\
Xinmiao & 0.1770 & 84.71 & 0.1027 & -0.2073 & 15.29 & 0.2510 \\
Xiulong & 0.1045 & 89.08 & -0.0511 & -2.1017 & 10.91 & 0.3328 \\
Yanbei & 0.1870 & 77.18 & 0.1253 & -0.1403 & 22.82 & 0.3203 \\
Yannan & 0.1271 & 87.60 & 0.0010 & -0.8623 & 12.40 & 0.7618 \\
Yingfang & 0.1639 & 84.31 & 0.0127 & -0.7369 & 15.69 & 0.2473 \\
Zitong & 0.2258 & 71.34 & 0.0552 & -0.3851 & 28.66 & 0.5082 \\
Overall & 0.1974 & 80.69 & 0.0406 & -0.5509 & 19.31 & 0.5744 \\
\hline
\end{tabular}

\subsubsection{Impacts of the Building Density on Housing Wealth Differentiation}

The expansion of auxiliary rooms' floor area widened the differentiation of rural housing wealth among villages. Rural houses occupied an average floor area of $131.72 \mathrm{~m}^{2}$ in Kangqiao Town, and there were slight differences among various villages in the intensification degree of rural floor area. Hehe had the smallest floor area of $101.54 \mathrm{~m}^{2} /$ house. In Huaqiang and Taiping, the floor area was relatively extensive; in contrast, in Xiulong and Rennan, the floor area was relatively intensive. Main rooms, auxiliary rooms and sheds accounted for $65.74 \%, 31.14 \%$ and $3.13 \%$ of the overall floor area, respectively; in specific, auxiliary rooms occupied a relatively large share of rural residential land.

The size of the housing area depends on residential land area and building story. Seen from the decomposition of the GCs for floor area and building story (Table 5), there was an absolute equilibrium of floor area among rural houses, but floor area played a dominant role in the differentiation formation of rural housing wealth, and the difference in its logarithm could explain $88.78 \%$ of the difference in the logarithm of total housing wealth. To be specific, in Taiping, Yingfang and Zitong, floor area had a positive Gini elasticity coefficient. This further suggests that the accumulation of rural housing wealth and housing differentiation were mainly realized through the horizontal expansion of residential land area at the rural-urban fringe. 
Table 5. GC decomposition of floor area and building story by villages in the study area.

\begin{tabular}{|c|c|c|c|c|c|c|}
\hline Villages & \multicolumn{3}{|c|}{ Floor Area } & \multicolumn{3}{|c|}{ Building Story } \\
\hline Dieqiao & 88.15 & 0.0245 & -0.2519 & 11.85 & 0.1074 & 0.2525 \\
\hline Hehe & 86.96 & 0.0016 & 0.1242 & 13.04 & 0.0000 & -0.1304 \\
\hline Huaqiang & 88.06 & 0.0396 & -0.0022 & 11.94 & 0.0406 & 0.0027 \\
\hline Rennan & 88.64 & 0.0372 & -0.0620 & 11.36 & 0.0617 & 0.0616 \\
\hline Shimen & 90.22 & 0.0339 & -0.2102 & 9.78 & 0.1391 & 0.2100 \\
\hline Taiping & 89.81 & 0.0487 & 0.4036 & 10.19 & -0.0996 & -0.4040 \\
\hline Tangxiang & 89.02 & 0.0288 & -0.1660 & 10.98 & 0.0884 & 0.1644 \\
\hline Xinmiao & 89.46 & 0.0276 & -0.2237 & 10.54 & 0.1150 & 0.2240 \\
\hline Zitong & 90.24 & 0.0502 & 0.0091 & 9.76 & 0.0449 & -0.0094 \\
\hline Overall & 88.78 & 0.0396 & 0.0176 & 11.22 & 0.0327 & -0.0176 \\
\hline
\end{tabular}

\section{Explanations for the Accumulation of Rural Housing Wealth in Kangqiao Town}

Kangqiao Town is a typical case of rural-urban fringe where the accumulation of rural housing wealth is affected by multiple formal and informal institutions during the social and economic transition period, such as the welfare distribution of rural homesteads, the rise of prices on urban commercial housing, and the development of informal housing markets at the rural-urban fringe. As shown by the above descriptive analysis, the location advantage of the rural-urban fringe and the extension and reconstruction of auxiliary rooms had key impacts on the preliminary differentiation of housing wealth. Based on that, the causes of accumulation differentiation for rural housing wealth were further explained (Figure 8). In China, the collective ownership of rural homestead basically realized "home ownership" for all rural households, and fundamentally safeguarded their rights to living and subsistence. As community members, rural residents submitted an application to their collective economic organization or villager committee for a homestead, on which they constructed their own houses. The rules for homestead use were rooted in socialist ideology, and it was not permitted to exchange or trade rural houses; in particular, urban residents were prohibited from purchasing rural housing land [47], so rural homesteads had no external mobility. However, industrial and commercial operations, and other informal economies have become increasingly active at the rural-urban fringe; rural housing wealth has emerged both as a foundation for negotiation among village collectives, villagers, developers, and local governments in urban renewal, and as a leverage for village collectives and villagers to obtain the increased appreciation income generated by urban development. In this context, some villagers constantly attempted to increase the building area and floor area through extension and reconstruction, or even through unapproved construction. Under the welfare distribution system, rural homesteads were free or very cheap, so the construction cost of rural housing was extremely low. Compared to commercial houses, whose prices are rising year by year at the rural-urban fringe, rural housing wealth has been gradually creating wealth effects. The active informal rural housing markets at the rural-urban fringe directly generated considerable property income, and the sharp contrast between the low construction cost of rural houses and the high prices of commercial houses created price disparities and wealth effects. Moreover, urban renewal and transformation transfer non-mobile and non-marketable rural houses into mobile and marketable buildings. All these factors combined to further stimulate rural residents to intensify their investment in house construction, especially through extending and reconstructing initial auxiliary rooms and other auxiliary facilities for circumventing planning constraints. Meanwhile, as urban development proceeded, farmers living at the rural-urban fringe had diverse sources of income, which further 
widened the disparities in family income and caused differences in the ability of villagers to invest in and accumulate housing wealth.

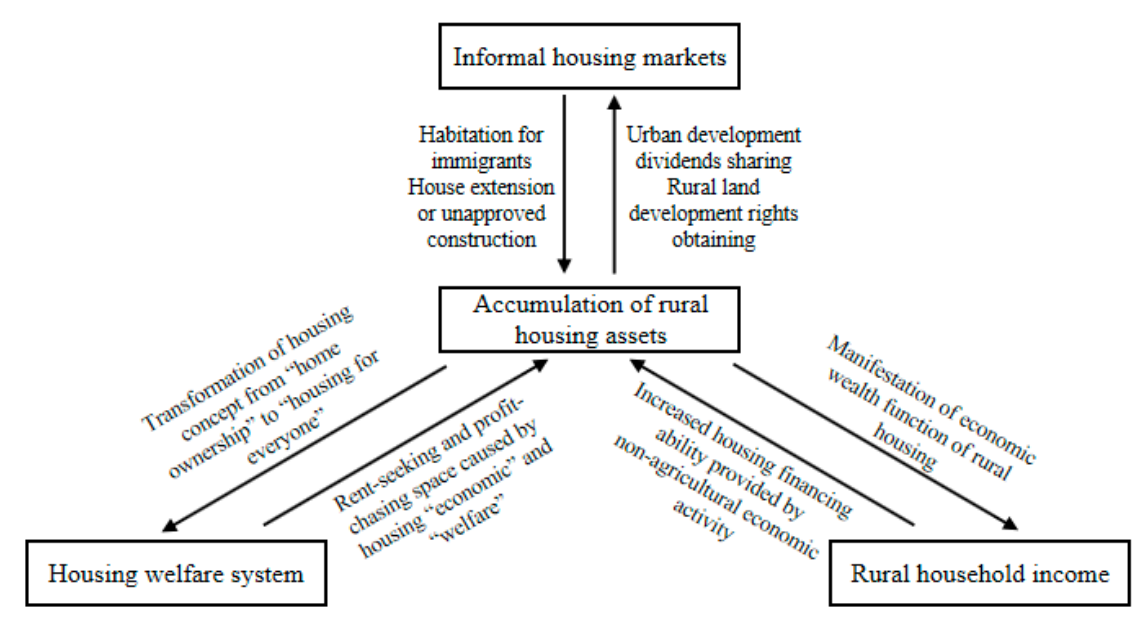

Figure 8. Causes for the accumulation of rural housing wealth the rural-urban fringe. Source: By the authors.

Industrial and commercial operations, and other informal economies generated property income at the rural-urban fringe, thus resulting in informal extension and reconstruction of rural housing. During China's social and economic transition, urban land and housing marketization are improving, but the reform of rural land institutions lags. Rural homesteads and houses are always non-marketable; they have prices but they are not commercially available. In particular, local governments monopolize the usage and ownership transformation of rural land at the rural-urban fringe where urbanization is advancing rapidly and houses are gaining in their development potential as well as wealth values. Despite that rural residents want land marketization and farmland conversion, they cannot spontaneously convert a rural homestead into urban construction land, thereby resulting in the formation of "urban villages" and other special social residential spaces at the rural-urban fringe. Combined with the social polarization of a migrant labor market as a result of urbanization, the rural-urban fringe has become an important habitation for low-income and homeless groups [48]. In the special period of social and economic transition, farmers living at the rural-urban fringe cannot market their properties due to land use control, so they turn to informal economies.

Free rural homesteads and the lack of supervision for rural development created rent-seeking and profit-chasing through informal extension and reconstruction of rural housing wealth. According to a report delivered at the 19th National Congress of the Communist Party in China, "we will press ahead with reform of the rural collective property system, and safeguard households property rights and interests". When it comes to family wealth and the functionality of rural houses, the problem becomes more complicated. With the transformation of the housing concept from "Home Ownership" to "Housing for All", a housing system characterized by multi-body supply, multi-channel guarantee, and simultaneous development of renting as well as purchasing, has emerged as the main way to guarantee "Housing for All". In rural housing system reform, the dual attributes of "economic" and "welfare" for rural houses creates a rent-seeking and profit-chasing space for unapproved construction. In 1978-2008, the house extension, reconstruction, or even unapproved construction carried out by villagers living at the rural-urban fringe for high property income were essentially rent-seeking behaviors. In this context, the "elite class" with strong economic strength, abundant political capitals, and high social status can easily accumulate housing wealth by means of increasing the floor area ratio, obtaining more rural homesteads, and engaging in unapproved construction [49]. As a result, the accumulation of housing wealth has led to wealth stratification at the rural-urban fringe.

The transformation of non-agricultural livelihoods and a higher amount of family income encouraged villagers to increase informal housing investment, further leading to the preliminary 
differentiation of rural housing accumulation. Since the reform and opening-up, the rapid growth of family income in China has produced two effects, that is, the rise in residents' consumption levels and the expansion of wealth [50]. Studies have found that the rapid accumulation of family wealth is attributable to the increase in housing property values, and housing wealth exerts a decisive effect on the inequality of family wealth. For instance, in 2002, housing property values accounted for $57.9 \%$ of family properties in China, but they contributed $66.32 \%$ to the inequality of total properties [50]. Driven by the external force of urbanization, urban and suburban villagers no longer rely on agricultural production as their primary means of livelihood at the rural-urban fringe. Instead, they engage in retail trade, dining, building, manufacturing, and other diverse non-agricultural livelihoods, which increases their family economic strength and financing ability, and reduces debt pressure that might limit the construction of new houses. In addition, villagers with urban household registration are entitled to equal development opportunities as urban residents, and they can share the achievements of urban development. Furthermore, some member of the "elite class" at the rural-urban fringe are also well-educated and open-minded towards new things and new income sources [51], so they can appreciate the economic wealth brought by houses. Therefore, the "elite class" with high income can easily turn their savings into housing wealth at the rural-urban fringe. As a consequence, the rights and interests of the agricultural population are jeopardized within this region, leading to a gradually intensified differentiation in the accumulation of rural housing wealth.

\section{Conclusions and Implications}

The rural residential land at the rural-urban fringe has become an attractive channel to revitalize stock construction land and break the bottleneck in urban development space [2]. Rapid urbanization, industrialization and the dual-track land ownership system have led to continuous increase in rural land value at the rural-urban fringe. In detail, there are active informal economies such as industrial and commercial operations at the rural-urban fringe, creating an obvious housing wealth effect [8]. Meanwhile, household non-agricultural income safeguards rural housing investments; the welfare attribute in rural homestead and the lack of explicit rural planning breed a rent-seeking and profit-chasing space for rural housing extension and reconstruction. In this case, it is significant to clarify the current distribution status of rural housing wealth at the rural-urban fringe, and to identify the origin and accumulation causes for continuously increasing rural residential land. Previous research has acknowledged that housing differentiation intensified during urban transition and in rural-urban regions [12,13]. Under the circumstances of ongoing rural market transitions in China, this study examines the status of rural housing wealth in detail using data for the comprehensive housing registration of 16 villages in Kangqiao Town, Shanghai, and we conclude with several findings and implications.

As a whole, rural housing wealth at the rural-urban fringe is characterized by high stock, large floor area, and frequent extension and reconstruction. Informal extension and reconstruction dominated by the expansion of auxiliary rooms has become a key way to directly increase the rural housing area in Kangqiao Town of Shanghai. Since 1978, 3492 rural houses have been constructed in Kangqiao Town, and $28 \%$ of them have been extended or reconstructed, for a cumulative number of 1466 occurrence. The GC of rural housing wealth is 0.1974 in Kangqiao Town, and the distribution per household is in equilibrium status. Most houses have a building area of 150-250 $\mathrm{m}^{2}$. However, some urban and suburban villages are adjacent to district center and have an obvious location advantage, as their difference coefficients are high, and village-level differentiation has preliminarily taken shape. In the survey, rural housing wealth of the entire sample has an average initial building area of $194.54 \mathrm{~m}^{2}$. After extension and reconstruction, building area per household increases to $241.09 \mathrm{~m}^{2}$. Main rooms are the most important component in rural housing. They have a stabilizing effect on the equality of rural housing. However, the building area and floor area proportions for auxiliary rooms are relatively high. The extension and reconstruction of auxiliary rooms from 1978 to 2008 provide a way to continuously increase rural housing wealth. Especially for the two poles of initial building area 
$\left(<150 \mathrm{~m}^{2}\right.$ and $\left.\geq 350 \mathrm{~m}^{2}\right)$, extension and reconstruction behaviors are typical, which directly changes the size distribution of housing wealth and drives housing wealth differentiation.

Overall, the findings in this study can contribute to policy and planning; for the surface reduction of rural collective construction land, as well as supporting policies for specific implementation of urban renewal and space optimization. The dual attributes of "economic" and "welfare" for rural houses create a rent-seeking and profit-chasing space for unapproved construction. Coupled with the lack of explicit planning for rural development, this leads to the preliminary wealth differentiation driven by the extension and reconstruction of auxiliary rooms. We suggest that the local government should pay more attention to auxiliary rooms, sheds, and other temporary facilities in land use planning. Moreover, the approval system, operating rules, declaration procedures, and legal boundaries for extended and reconstructed rural houses should be clarified to avoid unapproved construction. The governments should distinguish the valid portion from the illegal portion of housing wealth accumulated through unapproved construction to prevent illegal wealth from being "legitimized" with the market-oriented reform of rural collective construction land and the market-oriented operations of urban renewal.

Author Contributions: J.X.: Formal analysis, Data curation, Methodology, Writing-original draft. Y.C.: Conceptualization, Methodology, Writing-review \& editing, Funding acquisition. H.T.: Investigation, Resources. Y.L.: Investigation, Resources. All authors have read and agreed to the published version of the manuscript.

Funding: This research was supported by National Natural Science Foundation of China (number 71974068 and 71573099).

Acknowledgments: The authors thank L.H. for the improvement of English quality.

Conflicts of Interest: All authors declare no conflict of interest.

\section{Appendix A Descriptive Statistics for Rural Housing Wealth}

Table A1. Rural housing wealth before and after extension and reconstruction in the study area.

\begin{tabular}{|c|c|c|c|c|c|c|c|c|}
\hline & \multicolumn{4}{|c|}{ Building Area } & \multicolumn{4}{|c|}{ Floor Area } \\
\hline & $\begin{array}{c}\text { Current } \\
\left(\mathrm{m}^{2}\right)\end{array}$ & $\begin{array}{l}\text { Proportion } \\
\text { (\%) }\end{array}$ & $\begin{array}{c}\text { Initial } \\
\left(\mathrm{m}^{2}\right)\end{array}$ & $\begin{array}{l}\text { Proportion } \\
\text { (\%) }\end{array}$ & $\begin{array}{c}\text { Current } \\
\left(\mathrm{m}^{2}\right)\end{array}$ & $\begin{array}{l}\text { Proportion } \\
\text { (\%) }\end{array}$ & $\begin{array}{c}\text { Initial } \\
\left(\mathrm{m}^{2}\right)\end{array}$ & $\begin{array}{l}\text { Proportion } \\
\text { (\%) }\end{array}$ \\
\hline Main rooms & $639,016.76$ & 75.90 & $601,941.69$ & 88.61 & $302,357.45$ & 65.73 & $286,211.90$ & 82.61 \\
\hline Auxiliary rooms & $188,486.65$ & 22.39 & $75,441.50$ & 11.11 & $143,248.94$ & 31.14 & $58,310.34$ & 16.83 \\
\hline Sheds & $14,371.57$ & 1.71 & 1958.51 & 0.29 & $14,371.57$ & 3.12 & 1958.51 & 0.57 \\
\hline Overall & $841,874.98$ & 100 & $679,341.70$ & 100 & $459,977.96$ & 100 & $346,480.75$ & 100 \\
\hline
\end{tabular}


Table A2. Rural housing wealth by area groups for whole sample before and after extension and reconstruction in the study area.

\begin{tabular}{|c|c|c|c|c|c|c|c|c|c|c|c|c|}
\hline \multirow{3}{*}{$\begin{array}{c}\text { Group } \\
\left(\mathrm{m}^{2} / \text { House }\right)\end{array}$} & \multicolumn{6}{|c|}{ Before Extension and Reconstruction } & \multicolumn{6}{|c|}{ After Extension and Reconstruction } \\
\hline & \multicolumn{3}{|c|}{ Building Area } & \multicolumn{3}{|c|}{ Floor Area } & \multicolumn{3}{|c|}{ Building Area } & \multicolumn{3}{|c|}{ Floor Area } \\
\hline & $\begin{array}{c}\text { Summary } \\
\left(\mathrm{m}^{2}\right)\end{array}$ & $\begin{array}{c}\text { Mean } \\
\left(\mathrm{m}^{2} / \text { House }\right)\end{array}$ & Variance & $\begin{array}{c}\text { Summary } \\
\left(\mathrm{m}^{2}\right)\end{array}$ & $\begin{array}{c}\text { Mean } \\
\left(\mathrm{m}^{2} / \text { House }\right)\end{array}$ & Variance & $\begin{array}{c}\text { Summary } \\
\left(\mathrm{m}^{2}\right)\end{array}$ & $\begin{array}{c}\text { Mean } \\
\left(\mathrm{m}^{2} / \text { House }\right)\end{array}$ & Variance & $\begin{array}{c}\text { Summary } \\
\left(\mathrm{m}^{2}\right)\end{array}$ & $\begin{array}{c}\text { Mean } \\
\left(\mathrm{m}^{2} / \text { House }\right)\end{array}$ & Variance \\
\hline$<150 \mathrm{~m}^{2}$ & 71,935 & 98.00 & 37.30 & 42,843 & 58.37 & 19.39 & 134,571 & 183.34 & 113.92 & 81,816 & 111.47 & 75.97 \\
\hline $150-250 \mathrm{~m}^{2}$ & 453,487 & 201.37 & 21.36 & 234,240 & 104.01 & 14.66 & 529,305 & 235.04 & 61.90 & 290,601 & 129.04 & 47.19 \\
\hline $250-350 \mathrm{~m}^{2}$ & 127,237 & 288.52 & 26.09 & 58,500 & 132.65 & 26.04 & 147,520 & 334.51 & 70.06 & 73,750 & 167.23 & 57.71 \\
\hline$\geq 350 \mathrm{~m}^{2}$ & 26,682 & 410.49 & 63.00 & 10,899 & 167.67 & 33.21 & 30,479 & 468.91 & 120.23 & 13,810 & 212.47 & 77.72 \\
\hline Overall & 679,342 & 194.54 & 68.69 & 346,481 & 99.22 & 30.29 & 841,875 & 241.09 & 94.19 & 459,978 & 131.72 & 59.58 \\
\hline
\end{tabular}

Table A3. Comparison of rural housing wealth in the study area from 1978 to 2017.

\begin{tabular}{|c|c|c|c|c|c|c|c|c|c|c|c|c|c|c|}
\hline \multirow{2}{*}{ Period } & \multicolumn{2}{|c|}{ Sample Distribution } & \multicolumn{4}{|c|}{ Initial Housing Composition $\left(\mathrm{m}^{2} /\right.$ House) } & \multicolumn{4}{|c|}{$\begin{array}{l}\text { Housing Composition after Extension and } \\
\text { Reconstruction ( } \mathrm{m}^{2} / \text { House) }\end{array}$} & \multicolumn{4}{|c|}{ Change $\left(\mathrm{m}^{2} /\right.$ House $)$} \\
\hline & $\begin{array}{l}\text { Houses } \\
\text { Number }\end{array}$ & $\begin{array}{l}\text { Proporti-on } \\
\quad(\%)\end{array}$ & $\begin{array}{l}\text { Main } \\
\text { Rooms }\end{array}$ & $\begin{array}{l}\text { Auxiliary } \\
\text { Rooms }\end{array}$ & Sheds & Subtotal & $\begin{array}{l}\text { Main } \\
\text { Rooms }\end{array}$ & $\begin{array}{l}\text { Auxiliary } \\
\text { Rooms }\end{array}$ & Sheds & Subtotal & $\begin{array}{l}\text { Main } \\
\text { Rooms }\end{array}$ & $\begin{array}{l}\text { Auxiliary } \\
\text { Rooms }\end{array}$ & Sheds & Overal \\
\hline 1978-1987 & 1475 & 42.24 & 145.6 & 34.4 & 0.4 & 180.3 & 161.5 & 85.5 & 5.1 & 252.1 & 15.9 & 51.2 & 4.8 & 71.8 \\
\hline 1988-1997 & 750 & 21.48 & 183.2 & 24.7 & 0.5 & 208.3 & 196.8 & 65.2 & 5.2 & 267.2 & 13.6 & 40.5 & 4.7 & 58.8 \\
\hline 1998-2007 & 1159 & 33.19 & 199.6 & 4.8 & 0.9 & 205.2 & 202.0 & 10.3 & 2.4 & 214.7 & 2.4 & 5.5 & 1.5 & 9.5 \\
\hline 2008-2017 & 108 & 3.09 & 171.3 & 7.1 & 0.9 & 179.2 & 177.2 & 14.1 & 1.5 & 192.9 & 6.0 & 7.1 & 0.6 & 13.7 \\
\hline Overall & 3492 & 100 & 172.4 & 21.6 & 0.6 & 194.5 & 183.0 & 54.0 & 4.1 & 241.1 & 10.6 & 32.4 & 3.6 & 46.6 \\
\hline
\end{tabular}




\section{References}

1. Liang, X.; Yuan, Q.; Tan, X.; Li, Z. Territorialization of urban villages in china: The case of guangzhou. Habitat Int. 2018, 78, 41-50. [CrossRef]

2. Zhang, Z.; Liu, J.; Gu, X. Reduction of industrial land beyond Urban Development Boundary in Shanghai: Differences in policy responses and impact on towns and villages. Land Use Policy 2019, 82, 620-630. [CrossRef]

3. Wang, H.; Wang, L.; Su, F.; Tao, R. Rural residential properties in China: Land use patterns, efficiency and prospects for reform. Habitat Int. 2012, 36, 201-209. [CrossRef]

4. Tao, R.; Wang, R.M. “Urban villages” redevelopment and land system reform: Pearl River Delta experience. Int. Econ. Rev. 2014, 3, 26-55.

5. Zhao, P. An 'unceasing war' on land development on the urban fringe of Beijing: A case study of gated informal housing communities. Cities 2017, 60, 139-146. [CrossRef]

6. Wang, B.; Tian, L.; Yao, Z. Institutional uncertainty, fragmented urbanization and spatial lock-in of the peri-urban area of china: A case of industrial land redevelopment in panyu. Land Use Policy 2018, 72, 241-249. [CrossRef]

7. Song, Y.; Zenou, Y.; Ding, C. Let's not throw the baby out with the bath water: The role of urban villages in housing rural migrants in China. Urban Stud. 2008, 45, 313-330. [CrossRef]

8. Xu, Z.; Gao, X.; Wang, Z.; Gilroy, R.; Wu, H. An investigation of non-local-governed urban villages in China from the perspective of the administrative system. Habitat Int. 2018, 74, 27-35. [CrossRef]

9. Wu, F.; Zhang, F.; Webster, C. Informality and the development and demolition of urban villages in the Chinese peri-urban area. Urban Stud. 2013, 50, 1919-1934. [CrossRef]

10. Liu, R.; Liu, X.F. Division of rural classes and "Housing status Groups". J. Humanit. 2014, 5, 118-124.

11. Huang, Y.; Jiang, L. Housing inequality in transitional Beijing. Int. J. Urban Reg. Res. 2009, 33, 936-956. [CrossRef]

12. Fang, Y.; Liu, Z.; Chen, Y. Housing inequality in urban China: Theoretical debates, empirical evidences, and future directions. J. Plan. Lit. 2019, 13. [CrossRef]

13. Yu, A.T.W.; Wu, Y.; Shen, J.; Zhang, X.; Shen, L.; Shan, L. The key causes of urban-rural conflict in China. Habitat Int. 2015, 49, 65-73. [CrossRef]

14. Wang, Y.; Li, Y.; Huang, Y.; Yi, C.; Ren, J. Housing wealth inequality in China: An urban-rural comparison. Cities 2020, 96. [CrossRef]

15. Goffette-Nagot, F.; Sidibé, M. Housing wealth accumulation: The role of public housing. Reg. Sci. Urban Econ. 2016, 57, 12-22. [CrossRef]

16. Liu, Y.; He, S.; Wu, F. Housing differentiation under market transition in Nanjing, China. Prof. Geogr. 2012, 64, 554-571. [CrossRef]

17. Liu, H.; Meng, P.; Ma, K.; Wang, K.; Zhang, B. Study on reduction of construction land in the developed area: Reviews of the workshop on "Land Use Pattern Changing and Construction Land Reductionin the New Normal". China Land Sci. 2015, 29, 11-17.

18. Yang, Z.; Zhang, X.; Zhao, L. Dual role of housing consumption and investment: Reexamine correlation of housing and consumption in urban China. Econ. Res. J. 2014, 49 (Suppl. S1), 55-65.

19. Arrondel, L.; Lefebvre, B. Consumption and investment motives in housing wealth accumulation. A Fr. Study. J. Urban Econ. 2001, 1, 112-137. [CrossRef]

20. Hu, M.; Su, Y.; Ye, W. Promoting or inhibiting: The role of housing price in entrepreneurship. Technol. Forecast. Soc. Chang. 2019, 148. [CrossRef]

21. Betermier, S. Essays on the Consumption and Investment Decisions of Households in the Presence of Housing and Human Capital. Ph.D. Thesis, UC Berkeley, Berkeley, CA, USA, 2010; pp. 54-55.

22. Fu, S.; Liao, Y.; Zhang, J. The effect of housing wealth on labor force participation: Evidence from China. J. Hous. Econ. 2016, 33, 59-69. [CrossRef]

23. Begley, J.; Chan, S. The effect of housing wealth shocks on work and retirement decisions. Reg. Sci. Urban Econ. 2018, 73, 180-195. [CrossRef]

24. Fang, L.; Tian, C. Housing and marital matching: A signaling perspective. China Econ. Rev. 2018, 47, 27-46. [CrossRef] 
25. Piketty, T.; Goldhammer, A. Capital in the Twenty-First Century; The Belknap Press of Harvard University Press: Cambridge, MA, USA, 2014.

26. Arundel, R. Equity inequity: Housing wealth inequality, inter and intra-generational divergences, and the rise of private landlordism. Hous. Theory Soc. 2017, 34, 176-200. [CrossRef]

27. Luo, C. Polarization of resident's income and wealth distribution in China. Stat. Res. 2018, 35, 82-92.

28. Eduful, A.K.; Hooper, M. Urban migration and housing during resource booms: The case of Sekondi-Takoradi, Ghana. Habitat Int. 2019, 93, 102029. [CrossRef]

29. Bonnet, C.; Garbinti, B.; Grobon, S. Rising inequalities in access to home ownership among young households in France, 1973-2013. Econ. Et. Stat. Econ. Stat. 2018, 1, 117-138. [CrossRef]

30. Ruoppila, S.; Kahrik, A. Socio-economic residential differentiation in post-socialist Tallinn. J. Hous. Built Environ. 2003, 18, 49-73. [CrossRef]

31. Wu, L.; Bian, Y.; Zhang, W. Housing ownership and housing wealth: New evidence in transitional China. Hous. Stud. 2019, 34, 448-468. [CrossRef]

32. Tutuko, P.; Shen, Z. The effect of land use zonings on housing development: The introduction of cdl approach in the border area of Surabaya and Sidoarjo Regency, Indonesia. Procedia Soc. Behav. Sci. 2016, 227, 107-114. [CrossRef]

33. Sakay, C.; Sanoni, P.; DEng, T.H. Rural to urban squatter settlements: The micro model of generational self-help housing in Lima-Peru. Procedia Eng. 2011, 21, 473-480. [CrossRef]

34. Wang, L.; Cui, Y.; Song, S. The characteristics and influencing factors of urban residents' housing stratification in China: Based on the microcosmic survey data in Tianjin. Urban Dev. Stud. 2018, 25, 116-124.

35. Wei, Z.; Liu, Y.; He, S.; Mo, H. Housing differentiation in transitional urban China. Cities 2020, 96. [CrossRef]

36. Khan, A.R.; Riskin, C. Income and inequality in China: Composition, distribution and growth of household income, 1988 to 1995. China Q. 1998, 154, 221-253. [CrossRef]

37. Li, S.; Li, J.; Ouyang, A.Y. Housing and Household Wealth Inequality: Evidence from the People's Republic of China; (ADBI Working Paper 671); Asian Development Bank Institute: Mandaluyong, Philippines, 2017.

38. Hai-Min, L.; Yong-Xia, W.; Shen, J.S.; An-Nan, Z. Assessment of Social-Economic Risk of Chinese Dual Land Use System Using Fuzzy AHP. Sustainability 2018, 10, 2451. [CrossRef]

39. Logan, J.R.; Fang, Y.; Zhang, Z. Access to housing in urban China. Int. J. Urban Reg. Res. 2009, 33, 914-935. [CrossRef] [PubMed]

40. Niu, G.; Zhao, G. Living condition among China's rural-urban migrants: Recent dynamics and the inland-coastal differential. Hous. Stud. 2018, 33, 476-493. [CrossRef]

41. Chen, Y. Informal housing and community in Chinese megacities: Types Mech. Responses. Urban Plan. Int. 2019, 3402, 40-46. [CrossRef]

42. Song, X.; Xie, Y. Market transition theory revisited: Changing regimes of housing inequality in China, 1988-2002. Sociol. Sci. 2014, 18, 277-291. [CrossRef]

43. Zhang, L.; Ye, Y.; Chen, J. Urbanization, informality and housing inequality in indigenous villages: A case study of Guangzhou. Land Use Policy 2016, 58, 32-42. [CrossRef]

44. Cai, Y.; Xie, J.; Tian, C. Housing wealth change and disparity of indigenous villagers during urban village redevelopment: A comparative analysis of two resettled residential neighborhoods in Wuhan. Habitat Int. 2020, 99, 102162. [CrossRef]

45. Wang, H.; Su, F.; Wang, L.; Tao, R. Rural housing consumption and social stratification in transitional China: Evidence from a national survey. Hous. Stud. 2012, 27, 667-684. [CrossRef]

46. Ning, G.; Luo, L.; Qi, W. Study on the contributing factors of property income inequality. Econ. Res. J. 2016, 51, 116-187.

47. Chia, E.; Ho, P. Institutions in transition: Land ownership, property rights and social conflict in china. China J. 2006, 2055, 157-158. [CrossRef]

48. Wang, M.; Lin, X.; Ning, Y. Migrant populations, temporary residence, and urban village renovation: A survey of migrant settlements in Shanghai. City Plan. Rev. 2012, 36, 73-80.

49. Guo, Y.; Li, X.; Zhang, C. The myth of urban village redevelopment in central Guangzhou: A case study in the perspective of growth machine theory. Mod. Urban Res. 2017, 5, 44-50. 
50. Li, S.; Wan, H. Evolution of wealth inequality in China. China Econ. J. 2015, 8, 264-287. [CrossRef]

51. Liu, X.; Chen, Y.; Xie, L.; Zhang, W. Analysis of influence factors about farmers housing type selection based on the village regulation. J. Arid Land Resour. Environ. 2014, 28, 57-61. 